\title{
(1) \\ Revers \\ ENTRERIOS \\ Comerford, J; Bezerra, M. O; Palmeira, M. Questões e dimensões da política: anais do Encontro dos 20 anos do Núcleo de Antropologia da Política (NuAP). Rio de Janeiro (RJ): Papéis Selvagens, 2017. p. 448.
}

\author{
Wanderson Carlos Lima da Silva \\ Mestrando em Antropologia na Universidade Federal do Piauí \\ wandersoncoreiro@gmail.com
}

Celso de Brito

Doutor em Antropologia Social Professor Adjunto do Departamento de Ciências Sociais e do Programa de Pós-Graduação em Antropologia da Universidade Federal do Piauí celsodebrito@ufpi.edu.br

O livro Questões e dimensões da política é resultado da compilação de pesquisas apresentadas no encontro de comemoração dos 20 anos do Núcleo de Antropologia da Política $\mathrm{NuAP}^{1}$, que aconteceu na cidade do Rio de Janeiro, em 2017. Por sua natureza, o livro congrega 28 trabalhos que expressam bem a rica e diversificada produção científica da extensa rede de pesquisadores que hoje é o núcleo, que por sua vez, desde o seu início, se volta para a compreensão do conceito de "política" em diferentes contextos brasileiros ${ }^{2}$, segundo o ponto de vista de muitos coletivos que o operacionalizam em suas vidas cotidianas.

O livro contem em sua estrutura uma apresentação, 5 capítulos e uma conclusão. Esses capítulos são temáticos e emergem das mesas de discussões que compunham o evento. Em seus conteúdos estão artigos que foram apresentados em cada situação acompanhado de um texto final, produzido pelo coordenador da mesa, que discute as semelhanças e diferenças entre as pesquisas. Observa-se que as análises sobre a categoria "política" que formam essa obra são perpassadas por elementos de muitas outras dimensões da vida social, possibilitando que alguns dos temas trabalhados pudessem ser alocados justificadamente em dois ou mais dos capítulos que apresentaremos a seguir: 1 - Política, eleições e o cotidiano do Estado; 2 Movimentos Sociais; 3 - Conflitos e Violência; 4 - Família, parentesco e relações pessoais e; 5 Mobilidade, vizinhança, casa.

1 Institucionalizado no ano de 1997.

2 Com exceção do trabalho de Paiva, "Práticas e falas da violência em uma tríplice fronteira amazônica Brasil, Peru e Colômbia", todos os trabalhos do livro abordam localidades do território brasileiro. 
No primeiro capítulo, os autores procuram, por meio de análises etnográficas, descrever e analisar diferentes noções de "política", por vezes relacionadas ao "cotidiano do Estado", "movimentos sociais" e às "eleições". Talvez, justamente por ter entre os termos definidores desse capítulo alguns dos temas "clássicos" do NuAP, esse seja o capítulo composto por artigos mais diversificados entre si e, assim, apresenta a tônica de todo o livro: a tentativa de ampliar o campo de análise sobre a "política" e a ênfase na abordagem etnográfica que preza pela captação da "política" através de imponderáveis da vida cotidiana, oferecendo concepções insuspeitáveis àqueles que se debruçam sobre o tema mediante concepções da Ciência Política ou da Filosofia Política.

O segundo capítulo, por sua vez, apresenta pesquisas focadas majoritariamente em diferentes "movimentos sociais": desde aqueles voltados à conquista de moradia ou de terra; aqueles através dos quais é possível analisar disputas internas entre "grupos políticos" ou "facções", até formas de movimentos sociais que surgem por meio das redes sociais online. De forma geral, com ricas descrições etnográficas, essas pesquisas demonstram mecanismos sociais que concatenam diferentes atores, em diferentes níveis e segundo diferentes valores, atribuindo, assim, concomitantemente coerência e complexidade a formas organizacionais que, por mais que pairem nas manchetes dos jornais e telejornais, poucas são de fato conhecidas de perto e de dentro, o que demonstra a importância do uso do instrumental antropológico em pesquisas feitas em nossa própria sociedade, estranhando instituições familiares para em seguida elucidálas.

Duas categorias, dentre os inúmeros que podem qualificar relações sociais entre diferentes atores inseridos ou não em movimentos sociais estão o "conflito" e a "violência" que, tornadas categorias analíticas, servem como circunscrição do foco dos trabalhos do terceiro capítulo. As abordagens apresentadas no capítulo três visam tratar a noção de "violência" não como um qualificativo negativo em oposição semântica à positividade dos valores ideais da democracia, mas através da consideração dos sentidos elaborados e mantidos em diferentes coletivos, regidos por regimes de moralidade específicos que possibilitam diferentes sujeitos inseridos em distintos coletivos organizarem suas relações sociais através da gestão da "violência". Esses trabalhos enfatizam o conflito e violência presentes em contextos limítrofes, seja no sentido territorial geográfico ou no sentido administrativo, nos quais há sobreposições de múltiplos sistemas de valores e relações de poder.

O capítulo quatro é formado por trabalhos que discutem a relação entre "família", "parentesco" e "relações pessoais" em suas dimensões políticas. Percebe-se nele a preocupação de não recair em percepções que excluam, a priori, a sobreposição das dimensões "política" e "família" e que tenda a concebê-la como um "desvio". Mais uma vez, evidencia-se a proeminência das concepções nativas e a fuga de proposições generalistas.

Já no quinto e último capítulo, os artigos concentram-se na temática da mobilidade, permitindo perceber que a transição dos indivíduos entre os espaços não é aleatória, já que seguem padrões localizados culturalmente de acordo com valores acordados coletivamente. Aqui a sobreposição e articulação entre diferentes dimensões da vida social com a dimensão da "política" se torna evidente: o "sagrado", a "família", o "trabalho" conformam esquemas e itinerários que definem os ambientes nos quais sujeitos devam ou não transitar.

O conjunto de pesquisas reunidas neste livro revela ótimos usos do instrumental analítico da Antropologia em contexto ocidental moderno, mais do que isso, esses pesquisadores se debruçaram sobre uma das esferas centrais deste contexto, a política, demonstrando sua multiplicidade de acepções e a sua porosidade frente a outras dimensões da vida social. Além disso, o livro expressa outra característica importante do NuAP e da própria Antropologia: tratase de um grande empreendimento comparativo. 
Todas as etnografias do livro foram elaboradas em diferentes regiões do país e sob diversos temas que possibilitam o acúmulo de dados etnográficos sobre a definição de "política", próprias a diversos grupos específicos e pouco estudados, o que suscita revisões de teorias clássicas da Antropologia.

Como já foi aludido acima, diferentemente do que é pensando na Ciência Política, Sociologia e até em algumas abordagens da Antropologia Política brasileira, realizada sobretudo até os anos 1990, a "política" não pode ser tratada como um objeto de estudo previamente definido, corroborando assim com certa ideologia moderna, segundo a qual a vida social deve ser dividida em nichos e o político destacado da sociedade como instância autônoma. Antes, a Antropologia demonstrada neste livro convence de que a "política" deve ser pensada de forma a estar sobreposta e em constante interação com questões sociais, culturais, religiosas presentes em cada contexto etnográfico específico.

Pensar e analisar o que seria a "política" de maneira etnográfica e comparativa é também entender o quanto que as Ciências Sociais e Humanas estão longe de definições universais legítimas a seu respeito; é nesse ponto que os autores remetem o leitor ao cerne do projeto antropológico ao discutirem os resultados de estudos sobre grupos e coletivos humanos em suas especificidades, captando com sensibilidade e acuidade os múltiplos sentidos possíveis dessa dimensão central das sociedades ocidentais modernas. Essa é, sem dúvida, a mais profícua contribuição que o NuAP nos transmite desde sua fundação e que salta aos olhos ao ler o livro Questões e dimensões da política. 
Carlos Filadelfo

Natacha Simei Leal

(Orgs.)

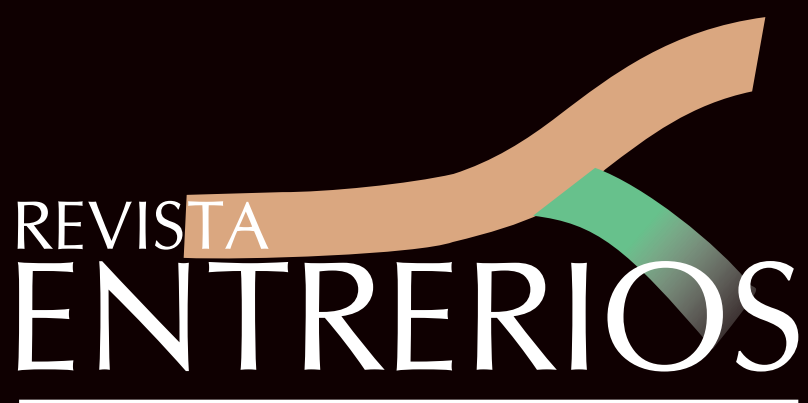

Revista do Programa de

Pós-Graduação em Antropologia da

Universidade Federal do Piaú 